\title{
Atmospheric concentrations, occurrence and deposition of persistent organic pollutants (POPs) in a Mediterranean coastal site (Etang de Thau, France)
}

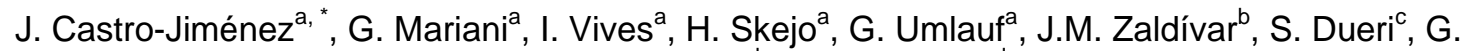 \\ Messiaen ${ }^{\mathrm{d}}$ and T. Laugier ${ }^{\mathrm{d}}$
}

${ }^{a}$ European Commission-Joint Research Centre, Institute for Environment and Sustainability, via E. Fermi 2749, 21027 Ispra (VA), Italy

${ }^{\mathrm{b}}$ European Commission-Joint Research Centre, Institute for Health and Consumer Protection, via E. Fermi 2749, 21027 Ispra (VA), Italy

${ }^{\mathrm{C}} \mathrm{CRH}$, UMR 212 EME, Institut de Recherche pour le Développement, Avenue Jean Monnet BP 171, 34203 Sète Cedex, France

${ }^{d}$ Ifremer, Environment and Resources Laboratory, Avenue Jean Monnet BP 171, 34203 Sète Cedex, France

* Corresponding author: J. Castro-Jiménez, Department of Environmental Chemistry, Institute of Environmental Assessment and Water Research (IDAEA-CSIC), C/Jordi Girona, 18-26, 08034 Barcelona, Spain., email address : javier.castro-jimenez@idaea.csic.es

\begin{abstract}
:
Atmospheric concentrations and deposition fluxes of PCDD/F and PCB have been evaluated over a 1year period in a Mediterranean coastal lagoon (Etang de Thau, France). Indicative PBDE air concentrations in the hot season are also reported in this work. $22,3,7,8-\mathrm{PCDD} / \mathrm{Fs}$ and $\Sigma 18 \mathrm{PCBs}$ (gas + particulate) air concentrations ranged from 67 to $1700 \mathrm{fg} \mathrm{m}-3$ and from 13 to $95 \mathrm{pg} \mathrm{m}-3$, respectively whereas $\Sigma 8$ PBDEs (gas + particulate) summer time levels varied from 158 to $230 \mathrm{pg}$ $\mathrm{m}-3$. The PCDD/F and PCB atmospheric occurrence over Thau lagoon and subsequent inputs to the surface waters are determined by an assemble of factors, being the seasonality of atmospheric concentration, the air mass origin and meteorological conditions important drivers. Total (wet + dry) $\sum 2,3,7,8-\mathrm{PCDD} / \mathrm{Fs}$ and $\Sigma 18 \mathrm{PCBs}$ deposition fluxes to Thau Lagoon waters are 117 and $715 \mathrm{pg} \mathrm{m}-2$ $\mathrm{d}-1$, respectively.
\end{abstract}

\section{Highlights}

PCDD/F and PCB atmospheric concentrations in Thau lagoon are typical from rural/semi-rural areas. PBDE atmospheric concentrations in Thau lagoon are typical from urban/industrial sites. PCDD/F and PCB atmospheric concentrations over Thau lagoon and inputs to surface waters are very variable, even changing between the same week of the month in two consecutive years.

Metallurgical industry may be a possible local source of PCDD/Fs in the Thau lagoon basin. Annual $\mathrm{PCBs}$ and PCDD/Fs atmospheric inputs are dominated by dry deposition

PCDD/F and PCB atmospheric concentrations over Thau lagoon and inputs to surface waters are very variable, even changing between the same week of the month in two consecutive years. 
Keywords: PCDD/F; Dioxin-like PCB; PBDE; Air; Water

\section{Introduction}

Persistent organic pollutants (POPs) present in the atmosphere may participate in exchange or deposition mechanisms that will determine their inputs to open waters and coastal areas of the sea ([Agrell et al., 2002], [Jurado et al., 2004] and [Jurado et al., 2005]). In addition, physico-chemical properties of POPs may favor long range atmospheric transport to other areas, even reaching remote zones ([Wania and Mackay, 1996] and [Lohmann et al., 1999a]). After deposition these contaminants are distributed into various environmental compartments, bioaccumulate and are considered potent toxicants, capable of producing a wide spectrum of adverse health effects in biota and humans ([Safe, 1984], [Safe, 1990] and [Vreugdenhil et al., 2002]). POP airborne concentrations in a specific region will be driven by local emissions as well as inputs arriving from other areas. Local inputs are mainly derived from on-site industrial and agricultural activities, vehicles, residential heating facilities and POPs mobilization from environmental reservoirs (e.g. soils, vegetation or water bodies) present in the area 
1 (Cousins and Jones, 1998, Lohmann et al., 2000; Br̈̈z et al., 2000; Kulkarni et al., 2008).

2 Airborne concentrations then will be determined by the pollutant amounts transported from

3 adjacent or more distant areas (Wania and McKay, 1996, Cleverly et al., 2007) and

4 governed by dominant air mass trajectories and winds.

6 Short-term surveys are usually performed in order to acquire punctual data on pollutant 7 ambient levels and in order to have a first estimation on the status of a given environment. 8 However, longer term campaigns are needed to better understand the system dynamics as 9 well as to provide comprehensive datasets. Data on POPs atmospheric concentrations and 10 deposition are also valuable for the environmental exposure assessment (as part of the risk 11 assessment) and for contaminant fate model development and validation. This work 12 presents and discusses a one year dataset on POPs atmospheric concentrations and 13 deposition (wet and dry) in a Mediterranean coastal location. The Thau lagoon (France) is 14 one of the largest Mediterranean lagoons with an intensive shell farming activity (oysters 15 and mussels), covering about $20 \%$ of the lagoon, and produces about 15000 tons of oysters 16 yearly (Gangnery et al., 2001). A detailed site description has been reported elsewhere 17 (Castro-Jiménez et al, 2008). The Thau lagoon is under intense anthropogenic pressure 18 (urban, industrial, port, agricultural and shell farming activities). POPs ambient levels have 19 been studied over the last decades in this system, being research mainly focused in the 20 aquatic compartment (i.e. sediment and mussels). Results from the French Monitoring 21 Network for Chemical Contamination (ROCCH) reported high contamination levels in 22 lagoon sediments of polycyclic aromatic hydrocarbons (PAHs) and polychlorinated 23 biphenyls (PCBs) and to a lower extent of organochlorine pesticides (DDTs, DDEs, DDDs, 
1 lindane) (ROCCH website; Tronczynski 1998; Léauté 2008). In addition, polychlorinated

2 dibenzo-p-dioxins and dibenzofurans (PCDD/Fs) and polybrominated diphenylethers

3 (PBDEs) ambient levels have been reported in sediment and mussels (Johansson et al.,

4 2006, Castro-Jiménez et al., 2008; Munschy et al., 2008; Hong et al., 2009) and PCB and

5 PCDD/Fs in water (Castro-Jiménez et al., 2008). However, little information is available on

6 POPs atmospheric levels and potential inputs to the lagoon. Results from a 1-week

7 experimental campaign in this ecosystem (Castro-Jiménez et al, 2008) and preliminary

8 modeled PCDD/F deposition fluxes (Dueri et al., 2010) highlighted the important role of

9 the atmosphere in the accumulation of PCDD/Fs in the lagoon.

10 In this work, the sampling period has been expanded to 1 year and the target contaminants

11 now include dioxin-like (DL)-PCBs and polybrominated diphenylethers (PBDEs), in

12 addition to PCDD/Fs and indicator PCBs. These three POPs families enter the environment

13 as a result of anthropogenic activities although their sources are different. PCDD/Fs occur

14 as unintentional byproducts of chemical manufacturing and incineration processes (Harrad

15 and Jones, 1992; Bruzy and Hites, 1996) whereas, PCBs were mainly used by the power

16 industry in electrical transformers, capacitors, hydraulic equipment, and as lubricants.

17 Current emissions to the environment are urban/industrial centers, landfills, open burning

18 of products containing PCBs, waste incinerations, accidental fires and re-volatilization from

19 environmental reservoirs (Cousins and Jones; 1998, Breivik et al., 2002). PBDEs constitute

20 an important group of brominated flame retardants and, unlike PCBs, are still being used as

21 additives in commercial products (especially in electrical equipment and textiles) to meet

22 fire safety regulations (Law et al., 2006). 
1 The objectives of this work are: (1) to gather in-depth knowledge on the PCDD/Fs, PCBs,

2 and PBDE atmospheric occurrence and ambient levels over Thau lagoon; (2) to estimate

3 the wet and dry atmospheric deposition fluxes of these POP families to surface waters of

4 this ecosystem.

\section{2. Experimental}

\section{$7 \quad 2.1$ Air sampling and site description}

8 Sampling equipment details and materials are presented in supporting information.

9 Integrated air samples were collected during the period February 2007-2008 by using a 10 high volume air sampler. The sampler was set up at the Ifremer Institute, located on the 11 south shore of Thau lagoon $\left(43^{\circ} 2351 \mathrm{~N}, 3^{\circ} 3934 \mathrm{E}\right)$. Location of the lagoon and the 12 sampling station has been described elsewhere (Castro-Jiménez et al, 2008), see Figure S1.

13 The sampling head module integrated a quartz fibre filter (QFF) of $102 \mathrm{~mm}$ diameter for 14 the air particulate phase collection and a polyurethane foam (PUF) plug of $65 \mathrm{~mm}$ diameter, $1575 \mathrm{~mm}$ length and $0.22 \mathrm{~g} \mathrm{~cm}^{-3}$ of density for the gas phase trapping, according to the U.S. 16 EPA TO-9A Method (US EPA, 1999a). The sampler was operated once a month for a 17 period of 7 days. A total of 13 samples was collected the average volume being $\sim 1400 \mathrm{~m}^{3}$. 18 Atmospheric temperature and pressure were recorded at the site. In addition, temperature, 19 precipitation, relative humidity and wind direction and speed for the sampling period were 20 obtained from the Météo-France meteorological station at Sète. Sampling details are 21 presented in Table S1. 
2 Details on the extraction and analytical procedures are presented in supporting information

3 (Text S1). Briefly, QFFs and PUFs were Soxhlet extracted separately with n-

4 hexane/acetone (220:30 volume/volume) for 24 hours after being spiked with ${ }^{13} \mathrm{C}$-labeled

$5 \mathrm{PCDD} / \mathrm{Fs}, \mathrm{PCBs}$ and PBDE internal standards. Extract purification was executed with an

6 automated clean-up system. This method, previously used in our laboratory, has proven a

7 high quality purification of the studied POPs (Vives et al., 2007). Two fractions were

8 collected: one containing mono-ortho PCBs, indicator PCBs and PBDEs and one

9 containing non-ortho PCBs and PCDD/Fs. Purified extracts were concentrated to near

10 dryness, ${ }^{13} \mathrm{C}$-syringe standards were added and a final volume of $30 \mu \mathrm{l}$ was adjusted.

11 Analyses of PCDD/Fs, PCBs and PBDEs were performed by isotopic dilution high

12 resolution gas chromatography ï high resolution mass spectrometry (HRGC-HRMS)

13 according to EPA1613, EPA 1668 and EPA 1614 methods (US EPA, 1994, 1999b, 2003).

\subsection{Quality assurance /Quality control (QA/QC)}

16 QFF were individually wrapped in aluminum foil, baked at $450{ }^{\circ} \mathrm{C}$ for $8 \mathrm{~h}$ and then stored

17 at $-18{ }^{\circ} \mathrm{C}$ in a sealed plastic bag until used. PUFs were Soxhlet extracted with acetone

18 during at least 24 hours before use, dried in a dessicator under vacuum and individually

19 wrapped in n-hexane rinsed aluminum foil. Both cleaned QFF and PUF were placed in a

20 Teflon sealed metallic transport container. Field blanks, consisting on cleaned QFFs and

21 PUF mounted in the sampling head, transported to the sampling area, mounted in the

22 sampler, dismounted and transported back to the laboratory were also collected and then

23 processed together with the samples. Procedural blanks (sampling) consisting on clean 
1 filters and PUFs (packed in the lab and untouched until analysis) were employed in order to

2 evaluate the potential contamination of samples due to handling and storage during the 3 sampling campaign. Procedural blanks (analysis) consisting on only extracting solvent

4 (Soxhlet extracted and cleaned-up as for the samples) were also processed for each batch of

5 fourteen samples. Procedural blanks showed similar levels to field blanks so no

6 contamination of samples during storage in the laboratory or transport occurred.

7 Breakthrough was tested in a previous campaign in the same place and similar conditions

8 and was found to be Òl0 \% (Castro-Jiménez et al., 2008).

$9 \mathrm{PCDD} / \mathrm{F}$ and PCB blank values were in general at limit of detection (LOD) levels except 10 for some congeners, for which the average concentrations estimated using the levels 11 measured in both PUF and filter blanks were Ò $8 \%$ of the concentrations measured in the 12 samples (Tables 1 and 2). A quantification problem occurred for PCDD/Fs and PCBs in the 13 particulate phase samples corresponding to April and November 2007. Concentrations for 14 those samples are not reported. Since PCDD/Fs were predominant in the particulate phase, 15 April and November total concentrations were excluded for discussion (Table 1). In the 16 case of total PCB concentrations (driven by gas phase concentrations), only gas phase 17 concentrations were considered for discussion for the mentioned months (Table 2).

18 Gas phase PBDE blank values for all congeners measured were in general equal or higher 19 than the concentrations measured in the samples except for three of them (corresponding to 20 the months of May, July and August 2007). Samples presenting high blank levels were not 21 considered. Particulate phase blank levels were high only in four samples, which were 22 discharged. For the accepted samples, X8PBDEs average blank values were Ò 4 and $15 \%$ 23 of the gas and particulate phase $\times 8 \mathrm{PBDE}$ concentrations (18\% in only one case), 
1 respectively (Table S6). Discussion on PBDE occurrence and ambient levels only

2 considered the three months were both gas and particulate phase concentrations were

3 available, corresponding to the warm period of the year (May, July and August 2007).

4 POPs concentrations reported were not corrected for blank values.

5 Standards (natives $+{ }^{13} \mathrm{C}$-compounds) were introduced in the chromatographic sequence to

6 evaluate possible variations during the time of analyses. Chromatographic peaks of target

7 compounds were only considered when complying with the following QA/QC criteria: (1)

8 the retention time of target compounds were $\pm 3 \mathrm{~s}$ of those observed for the corresponding

9 standards; (2) experimental isotopic ratios of natives compounds were within $\pm 20 \%$ of the

10 theoretical ratio and (3) peaks were at least 3 times higher than the noise. LODs were

11 calculated on the basis of a signal to noise ratio of $3 / 1$ in real samples (therefore taking into

12 account the matrix effect and the influence of both processing and analytical steps) and

13 ranged from 0.01 to $5 \mathrm{fg} \mathrm{m}^{-3}$ depending on the POPs family, congener and sample analyzed.

14 PCDD/F, PCB and PBDE average recoveries throughout the whole analytical method 15 (extraction-cleanup-analysis) ranged from 46 to $84 \%, 34$ to $97 \%$ (except for CBs-28 and 16 52: 21\%) and 62 to $130 \%$ (except for BDE-28: 38\%), respectively. Results were corrected 17 by recoveries (isotopic dilution method).

\section{2.4. Wet and dry deposition fluxes}

20 Atmospheric concentrations (gas and particle phase) of PCBs and PCDD/Fs were combined 21 with temperature and rainfall measured at the meteorological station in Sète in order to 22 estimate the wet and dry deposition fluxes as well as to study their seasonality in Thau 23 lagoon. Gaseous and particulate atmospheric concentrations were interpolated using a 
1 polynomial fitting approach in order to have a continuous time series. The methodology

2 used to calculate dry and wet deposition is similar to the one described in Castro-Jiménez et

3 al. (2009) to estimate PCBs deposition in the Lago Maggiore area. Equations and approach

4 used are described in detail in the supplementary material (Text S2). The results from this

5 calculation only provide indicative estimation of fluxes that should be eventually validated

6 by experimental measurements.

\section{$8 \quad$ 2.5. Statistics}

9 Principal component analysis (PCA) was performed using the software package SPSS. As 10 proposed by Zhu et al. (2008) data were normalize before PCA calculation in order to 11 reduce the effect of concentration differences among congeners. OCDD concentration 12 dominated the Thau samples and most of the emission source fingerprints, so the 13 mentioned congener could overwhelm the influence of less dominant congeners during 14 normalization by relative concentration. Therefore, the congener profiles for the 16 possible $152,3,7,8$ substituted congeners without OCDD were normalized by dividing the 16 concentration of each congener by the sum of the concentration of these 16 congeners. 17 OCDD concentration was normalized by dividing its concentration by the sum of the 18 concentrations of all 17 possible 2,3,7,8 substituted congeners.

\section{3. Results and Discussion}

223.1 Ambient concentrations

23 3.1.1. PCDD/Fs and PCBs 
$1 \times 2,3,7,8-\mathrm{PCDD} / \mathrm{Fs}$ and $\times \mathrm{Cl}_{4-8} \mathrm{DD} / \mathrm{Fs}$ (gas + particulate) air concentrations ranged from 67

2 to 1700 and from 175 to $4455 \mathrm{fg} \mathrm{m}^{-3}$, respectively (Table 1). Higher levels were observed 3 during the winter months, in particular on December 2007 and February 2008. PCDD/F gas

4 and particulate phase concentrations are presented in Tables S2 and S3, respectively 5 (supplementary material). $\times 2,3,7,8-\mathrm{PCDD} / \mathrm{F}$ and $\times \mathrm{Cl}_{4-8} \mathrm{DD} / \mathrm{F}$ atmospheric concentrations 6 were driven by levels in the particulate phase ranging from 50 to 1500 and from 95 to 3300

$7 \mathrm{fg} \mathrm{m}^{-3}$, respectively. Gas phase concentrations were lower and less variable (5 ï 60 and 65 ï

$8475 \mathrm{fg} \mathrm{m}^{-3}$ for $\times 2,3,7,8-\mathrm{PCDD} / \mathrm{Fs}$ and $\times \mathrm{Cl}_{4-8} \mathrm{DD} / \mathrm{Fs}$, respectively) during the whole year 9 except for November 2008 where values of 290 and $1730 \mathrm{fg} \mathrm{m}^{-3}$ were registered for $10 \times 2,3,7,8-\mathrm{PCDD} / \mathrm{Fs}$ and $\times \mathrm{Cl}_{4-8} \mathrm{DD} / \mathrm{Fs}$, respectively. Higher $\mathrm{PCDD} / \mathrm{Fs}$ concentrations in 11 winter time have been reported in literature. These variations have been attributed to a 12 combined effect of several factors, such as the atmospheric mixing layer height seasonal 13 cycle (exhibiting considerably lower height in winter time and therefore less favoring 14 dispersion of local emissions) and the increase of diffuse domestic heating (combustion) 15 sources during colder conditions (Lohmann and Jones, 1998; Lee et al., 1999; Coutinho et 16 al., 2007).

18 Atmospheric concentrations of dioxin-like (CB-81, -77, -105, -114, -118, -123, -126, -156, $19-157,-167,-169,-189)$ and indicator (CB-28, -52, -101, -153, -138, -180) PCBs are 20 reported in this work (Table 2). XDL-PCB ambient concentration (gas + particulate) varied 21 from 1 to $8 \mathrm{pg} \mathrm{m}^{-3}$, whereas Xindicator PCB levels ranged from 11 to $87 \mathrm{pg} \mathrm{m}^{-3}$. Ambient 22 air concentrations over Thau lagoon are dominated by the PCB concentrations in the gas 23 phase, contrary to $\mathrm{PCDD} / \mathrm{Fs}$. PCB gas and particulate phase concentrations are presented in 
1 Tables S4 and S5, respectively (supplementary material). Levels in the gas phase varied

2 from 1 to 7 and from 9 to $84 \mathrm{pg} \mathrm{m}^{-3}$ for $\times \mathrm{DL}-\mathrm{PCB}$ and $\times$ indicator PCB, respectively,

3 whereas values in the particulate phase ranged from 0.1 to 0.7 and 0.5 to $7 \mathrm{pg} \mathrm{m}^{-3}$ for $\times \mathrm{DL}$ -

4 PCBs and Xindicator PCBs, respectively. The highest concentration was measured on

5 February 2008 but not a clear seasonal trend was observed. Total $\mathrm{WHO}_{98}$ TEQ levels

6 (PCDD/Fs + DL-PCB) ranged from 3 to $143 \mathrm{fg} \mathrm{m}^{-3}$ and were clearly dominated by the

7 PCDD/F contribution, in particular in winter months (Tables 1 and 2). PCDD/Fs and PCB

8 concentrations measured are in agreement with the values found in Thau lagoon in 2005

9 when $\times 2,3,7,8-\mathrm{PCDD} / \mathrm{Fs}$ and indicator PCB concentrations ranged from 186 to $1440 \mathrm{fg} \mathrm{m}^{-3}$

10 and from 31 to $57 \mathrm{pg} \mathrm{m}^{-3}$, respectively. In addition, results confirm the previous observation

11 that POPs levels in the lagoon airshed are in general typical of those reported for rural or

12 semi-rural areas in spite of the anthropogenic impact in this lagoon (Castro-Jiménez et al.,

132008 and references therein)

15 3.1.2. PBDEs

16 Ambient air concentrations of PBDE (BDE-28, -47, -100, -99, -154, -153, -183 and -209)

17 are reported in this work for three months. X8PBDEs total air concentrations (gas + 18 particulate) varied from 158 to $230 \mathrm{pg} \mathrm{m}^{-3}$ (Table 3). PBDE atmospheric concentrations in 19 Thau lagoon during summer are driven by gas phase levels which ranged from 156 to 227 $20 \mathrm{pg} \mathrm{m}^{-3}$, whereas particulate phase levels ranged from 1 to $18 \mathrm{pg} \mathrm{m}^{-3}$ (Table S6). These 21 concentrations correspond only to the period May-August 2008 (see section 2.3.) when 22 temperatures between 19 and $22{ }^{\circ} \mathrm{C}$ were recorded (Table S1) and probably higher 23 volatilization occurred. Concentration for the same set of PBDE congeners (except BDE- 
1209 ) ranging from 0.5 to $250 \mathrm{pg} \mathrm{m}^{-3}$ over Europe has been reported in a continental study

2 conducted using passive samplers (Jaward et al., 2004). Concentrations measured in Thau

3 lagoon are on the higher end of this European range, being closer to values measured in

4 inland aquatic environments with more urban influence (Mariani et al., 2008; Bogdal et al.,

5 2010) and similar to those reported for urban or industrial sites (Cetin and Odabasi, 2007).

6

\section{3.2.1. Congener patterns}

10 Contaminant congener patterns (gas + particulate) are presented in Figure 1.

$11 P C D D / F s$ : Two groups of patterns were identified. The first group (T1, T2, T7, T11 and $12 \mathrm{~T} 12)$ was characterized by a significantly higher predominance ( $t$-test, $p<0.001)$ of higher 13 chlorinated dioxins compared to the second group (T4-6, T8, T9 and T13). OCDD 14 accounted in the first group for the $48 \pm 3 \%$ and $19 \pm 1 \%$ of the $\times 2,3,7,8-\mathrm{PCDD} / \mathrm{Fs}$ and $15 \times \mathrm{Cl}_{4-8} \mathrm{DD} / \mathrm{Fs}$, respectively (Figure $1 \mathrm{~A}$ ). The second group was characterized by greater predominance of furans ( $t$-test, $p<0.009-0.018$ ), congener 1,2,3,4,6,7,8-HpCDF accounting

17 for the $13 \pm 4 \%$ of the $\times 2,3,7,8-\mathrm{PCDD} / \mathrm{Fs}$, and TCDF accounted for the $22 \pm 2 \%$ of the $18 \times \mathrm{Cl}_{4-8} \mathrm{DD} / \mathrm{Fs}$ (Figure 1B). The existence of these two situations indicates that there is not a 19 net and uniform pattern arriving to the area and therefore different sources may be driving 20 the overall PCDD/F atmospheric pattern (and concentrations) over Thau lagoon and 21 subsequent loads to surface waters. Although some indications of sink/source profiles were 22 found for both groups of patters, not a clear evaluation on their distant (sink) / local 
1 (source) characteristics could be made according to the classical approach based on

2 congener pattern differences (Brubaker and Hites 1997, Lohmann and Jones, 1998).

$4 \quad P C B$ s and PBDEs: DL-PCB pattern was characterized by a predominance of CB-118 (65 \pm

$51 \%)$ followed by CB-105 (20 $\pm 1 \%)$. Similar patterns were observed both in the gas and

6 the particular phases. Regarding indicator PCBs, congeners -101 (25 $\pm 4 \%),-153(20 \pm 4 \%)$

7 and $-52(23 \pm 8 \%)$ were more abundant. Particulate phase pattern presented high variability

8 depending on the sampling, most probably due to the low particle phase indicator PCB

9 concentrations. Congeners BDE-47 $(45 \pm 0.5 \%)$ and $-99(39 \pm 0.2 \%)$ predominated in the

10 total (gas + particle) and in the gas phase patterns, whereas an enrichment of BDE-209 was

11 observed in the particulate phase pattern, accounting for the $70 \pm 17 \%$ of the pattern.

13 3.2.2. Influence of air mass origin

14 To further investigate the atmospheric occurrence of POPs (in particular PCDD/Fs) in the

15 Thau lagoon airshed, the air mass origins during the sampling events were studied. Five 16 days (120h) back trajectories (BT) were calculated using the HYSPLIT model. Trajectories 17 were generated from the sampling location every $6 \mathrm{~h}$ at four different heights $(50,100,500$ 18 and $1000 \mathrm{~m}$ ) above the sea level. BT frequency plots are presented in Figure 2. The highest 19 PCDD/Fs concentrations (December 2007 and February 2008, Table 1) corresponded to a 20 European continental influence of air masses (Figure 2). However, the majority of the 21 trajectories came from the NW Atlantic or had an Atlantic/ marine influence (Figure 2). 22 During the corresponding sampling events lower concentrations were measured in 
1 particular for the months of June, July, and August 2007 when trajectories exhibited a clear

2 and predominant Atlantic influence.

3 The studied area is frequently under influence of strong ó rramontaneôwind events, blowing

4 from NW direction. Higher wind speeds are associated with a contaminant dilution effect

5 due to a greater height of the mixed boundary layer, the dispersion of local emissions and

6 the introduction of áleanerôair in the local environment (Lohmann et al., 1999b, 2003).

7 There will be a combined effect between air masses coming from the Atlantic (low

8 pollutant loads) and local strong winds events. Under these conditions, PCDD/Fs ambient

9 levels and inputs to the aquatic system will decrease. On the contrary, when air masses are

10 coming from continental Europe and no local winds occur, a higher atmospheric load of

11 pollutants can be expected therefore increasing atmospheric inputs to the lagoon (see also

12 fluxes discussion below). In addition, the PCDD/Fs seasonality (higher concentrations in

13 winter time, section 3.1.1.) may certainty play an important role on the final PCDD/Fs

14 atmospheric levels over Thau lagoon and deposition into the system.

15

16 Interestingly, $\mathrm{PCDD} / \mathrm{F}$ and $\mathrm{PCB}$ concentrations measured February 2008 were more than 3-

17 fold times higher than the levels measured in the same week of February 2007 (Table1).

18 We hypothesize that these differences can be attributed to a combined effect of a different

19 air mass origin and meteorological conditions during the sampling events. Trajectories

20 corresponding to the sample taken in February 08 came from continental Europe (Figure 2),

21 potentially transporting a higher load of pollutants (see above) whereas air masses

22 trajectories corresponding to the sample February 07 had an Atlantic influence. That could

23 also explain the different congener patterns observed (Figure S2) for both samples. In 
1 addition, precipitation events were registered in the sampled week of February 07

$2(44.6 \mathrm{~mm})$ whereas almost no precipitation was recorded in February $08(0.2 \mathrm{~mm})$ (Table

3 S1). This may contribute as well to the decreasing of ambient levels measured in February

42007 since airborne contaminants were most probably washout from the atmosphere.

5 Indeed, wet deposition fluxes supported this hypothesis. PCDD/F and PCB fluxes in

6 February 07 are considerably higher than those calculated for February 08 (see fluxes

7 discussion below). This observation highlights the fact that the atmospheric occurrence and

8 final deposition of POPs in Thau lagoon may be very variable, even changing between the

9 same week of the month in two consecutive years.

\section{3.2.3. Possible sources of PCDD/Fs in Thau Lagoon}

12 Several industry types operate in the Languedoc-Roussillon region, where the Thau lagoon 13 is located, being urban waste incinerator, chemical and metallurgic industries the most 14 abundant (RFEP website). The urban waste incineration industry has been historically 15 reported as the most likely emission source of PCDD/Fs in the Languedoc-Roussillon 16 region. The second largest facility in the area is located in Sète, gathering residues from all 17 Thau lagoon basin and processing more than 60000 ton/year (PRQA, 1999). PCA was 18 carried out in order to investigate the most likely PCDD/Fs source in the area based in our 19 experimental measurements. The statistical analysis included the PCDD/Fs atmospheric 20 concentrations generated in Thau lagoon and most common PCDD/F emission source 21 fingerprints (including the above mentioned among others) as reported in Buekens et al. 22 (2000), Carroll et al. (2001), Zhu et al. (2008), Tysclind et al. (1993), Hagenmaier et al. 23 (1994), and Lin et al. (2007) (Figure 3). The PCA provided a single three-dimensional 
1 model that accounted for more than $80 \%$ of the variance (Figure 3). The first principal

2 component is highly and positively correlated with pentaCDD, hexaCDD and hexa CDF.

3 The second principal component is inversely correlated with OCDD. The two types of

4 congener pattern found in the Thau lagoon presented in this test relatively similar

5 fingerprints in comparison to the well defined emission fingerprints tested. The Thau

6 samples were differentiated from air profiles of sites with no direct PCDD/F emission

7 impact (background) and presented a relative influence of metallurgical industry.

8 It has been reported that the main PCDD/F emission source (municipal solid waste

9 incinerators, MSWI) in Europe has been replaced by metallurgic industry related sources in

10 the last two decades (Quaß et al., 2004; Martinez et al., 2010). That seems to be the

11 situation for Thau Lagoon area. This fact highlights the necessity of updating PCDD/Fs

12 emission inventories in the area in order to evaluate the relative influence of $\mathrm{PCDD} / \mathrm{F}$

13 sources in the region. In addition, dedicated sampling campaigns to be carried out closer to

14 main suspected sources are needed to confirm this first observation and in order to gather a

15 deeper insight on the PCDD/Fs source apportionment in the area.

\section{3.3. Atmospheric deposition}

18 Daily wet and dry deposition fluxes of $\mathbb{2} 2,3,7,8-\mathrm{PCDD} / \mathrm{Fs}$ and $\mathbb{E} 18 \mathrm{PCB}$ sere calculated

19 for the period covered by the sampling campaign (February 2007-2008). PBDE fluxes are

20 not reported since no year round-data was available. Averaged daily fluxes are in the lower

21 end of those reported in literature for other coastal and inland urban/suburban sites (Tables

22 S7-S8 and reference therein). PCDD/Fs dry deposition fluxes (5 - $\left.170 \mathrm{pg} \mathrm{m}^{-2} \mathrm{~d}^{-1}\right)$ have

23 been reported for the Mediterranean open waters (Castro-Jiménez et al., 2010), whereas 
$1 \times 54$ PCB dry deposition fluxes (0.1-1.1 $\left.\mathrm{ng} \mathrm{m}^{-2} \mathrm{~d}^{-1}\right)$ were calculated for a marine

2 background sampling station in the Eastern Mediterranean (Mandalakis et al., 2005).

3 Calculated dry deposition fluxes in Thau lagoon for PCDD/Fs $\left(64 \mathrm{pg} \mathrm{m}^{-2} \mathrm{~d}^{-1}\right)$ and $\mathbb{E} 18 \mathrm{PCBs}$

$4 \quad\left(0.4 \mathrm{ng} \mathrm{m}^{-2} \mathrm{~d}^{-1}\right)$ are within this range.

6 The yearly dry, wet and total atmospheric deposition fluxes as mass and toxic equivalents

$7 \mathrm{WHO}_{98}-\mathrm{TEF}$, for PCDD/Fs and DL-PCBs) are presented in Table 4. On a yearly basis,

8 atmospheric inputs of PCBs and PCDD/Fs are dominated by dry deposition. TEQ fluxes

9 are dominated by PCDD/Fs (97-98\% of total TEQ flux) while DL-PCB play a minor role,

10 even though the mass flux of PCBs is higher than the one for PCDD/Fs. The averaged daily

11 TEQ flux (PCB + PCDD/Fs) was estimated to be 4.3 pg TEQ $\mathrm{m}^{-2} \mathrm{~d}^{-1}$. Total (wet + dry)

$12 \mathbb{2} 2,3,7,8-\mathrm{PCDD} / \mathrm{Fs}$ and $\mathbb{2} 18 \mathrm{PCB}$ mass inputs to Thau Lagoon waters (70 $\mathrm{km}^{2}$ surface) are $13 \quad 3$ and $18 \mathrm{~g} \mathrm{y}^{-1}$, respectively.

14 The monthly dry fluxes of DL-PCBs and PCDD/Fs show a seasonal pattern with generally

15 higher dry deposition fluxes during the cold season and lower input during summer (Figure

16 4). The seasonal trend is less pronounced for the indicator PCBs, partly because the more 17 volatile PCBs (28, 52 and 101) show higher dry deposition fluxes during summer. The 18 overall dry deposition is still more important in winter. For all the measured compounds, 19 the wet deposition pattern depends on the occurrence of rainfall and peaks during the month 20 of May 2007.

21 The dominance of dry deposition compared to wet deposition on a yearly basis for the Thau

22 Lagoon system is likely to be a regional attribute of the relatively dry climate. In other 23 systems characterized by higher rainfall a dominance of wet deposition has been reported 
1 for PCDD/Fs such as for the Bayreuth Region and the Great Lakes (Kaupp and McLachlan

2 1999; Zhang et al., 2009).

4 3.4. Conclusions

5 A 1-year dataset of PCDD/Fs and PCBs atmospheric concentrations and indicative PBDE

6 summer concentrations in Thau lagoon has been generated. These data are now available

7 for contaminant fate modeling development and validation. In addition, they provide

8 exposure data for risk assessment in Mediterranean coastal lagoons. PCDD/Fs and PCBs

9 ambient levels over Thau lagoon are typical from rural/semi-rural areas whereas PBDE

10 levels (in summer time) are typical from urban/industrial sites. The PCDD/F and PCB

11 atmospheric occurrence over Thau lagoon and subsequent inputs to the surface waters are

12 determined by an assemble of factors, being the seasonality of atmospheric concentration,

13 the air mass origin and meteorological conditions important drivers. Different sources may

14 be responsible for the PCDD/Fs atmospheric concentrations over Thau lagoon, metallurgic

15 industry probably being an important source in the region. PCDD/F and PCB yearly inputs

16 (mass and toxic equivalent) to the lagoon waters showed the importance of wet deposition

17 during rainy events although on a yearly basis dry deposition is dominant. A seasonal

18 pattern of atmospheric fluxes emerged from our calculations showing higher fluxes during

19 the cold season. These facts highlight the álynamicô character of POPs atmospheric

20 concentrations and subsequent deposition in a Mediterranean coastal location, even

21 changing between the same week of the month in two consecutive years. In order to

22 properly evaluate the environmental/human exposure to these pollutants in this ecosystem

23 and in general in semi-enclosed coastal lagoons, an assessment of the POP-airshed is 
1 required. Since the experimental results point to high environmental variability, model

2 simulations are useful to evaluate the load of POPs into coastal lagoons and to complement 3 experimental data.

4

5 


\section{Acknowledgments}

2 This work was supported by the Thresholds of Environmental Sustainability Project

3 (European Commission FP6, SUST-DEV, IP Project 003933-2) and Ifremer laboratory

4 LER/LR. We would like to acknowledge Dr. H.I. Reuter for the air mass back trajectory 5 calculations and corresponding plots.

6

7

8 


\section{References}

3 Agrell C., Larsson P., Okla L., Agrell J., 2002. PCB congeners in precipitation, wash out

4 ratios and depositional fluxes within the Baltic Sea region, Europe. Atmos. Environ. 36, $5 \quad 371 \ddot{1} 383$

6

7 Breivik, K., Sweetman, A., Pacyna, J.M., and Jones, K.C., 2002. Towards a global

8 historical emission inventory for selected PCB congeners-a mass balance approach 2.

9 Emissions. Sci. Total Environ. 290, 199-224.

11 Bogdal C, Scheringer M., Schmid P., Bläuenstein M., Kohler M., HungerbühlerK., 2010. 12 Levels, fluxes and time trends of persistent organic pollutants in Lake Thun, Switzerland:

13 Combining trace analysis and multimedia modeling. Sci. Total Environ. 408, 3654 ï 3663

14

15 Broz J., Grabic R, Kilian J., Lojkasek M, Marklund S, Ocelka T, Pekarek V., Pribyl J., 16 Tydlitat V., Vyska J., 2000. The effect of oils on PAH, PCDD, PCDF, and PCBs emissions 17 from a spark engine fueled with leaded gasoline. Chemosphere 41, $1905 \mathrm{I} 11$.

19 Brubaker W.W. JR. and Hites R.A., 1997. Polychlorinated dibenzo-p-dioxins and 20 dibenzofurans: gas-phase hydroxyl radical reactions and related atmospheric removal. 21 Environ. Sci. Technol. 31, 1805-1810. 
1 Bruzy L.P. and Hites, R.A.,1996. Global mass balance for polychlorinated dibenzo-p-

2 dioxins and dibenzofurans. Environ. Sci. Technol. 30, 1797-1804.

3

4 Buekens A, Cornelis E, Huang H, Dewettinck T., 2000. Fingerprints of dioxin from thermal 5 industrial processes. Chemosphere 40:1021ї 4.

6

7 Carroll Jr WF, Berger TC, Borrelli FE, Garrity PJ, Jacobs RA, Ledvina J, Lewis J.W.,

8 McCreedy R.L., Smith T.P., Tuhovak D.R., and Weston A.F., 2001. Characterization of

9 emissions of dioxins and furans from ethylene dichloride, vinyl chloride monomer and 10 polyvinyl chloride facilities in the United States. Consolidated report. Chemosphere 43, $11 \quad 689 \ddot{1} 700$

13 Castro-Jiménez J., Deviller G., Ghiani M., Loos R., Mariani G., Skejo H. , Umlauf G., 14 Wollgast J., Laugier T., Héas-Moisan K., Léauté F., Munschy C., Tixier C., TronczyCkki J., 15 2008. PCDD/F and PCB multi-media ambient concentrations, congener patterns and 16 occurrence in a Mediterranean coastal lagoon (Etang de Thau, France). Environ. Pollut. $17 \quad 156,123-135$.

18

19 Castro-Jiménez J., Dueri S., Eisenreich S.J., Mariani G., Skejo H., Umlauf G. and Zaldívar 20 J.M., 2009. Polychlorinated biphenyls (PCBs) in the atmosphere of sub-alpine northern 21 Italy. Environ. Pollut. 157, 1024-1032 
1 Castro-Jiménez J, Eisenreich S.J., Ghiani M., Mariani G., Skejo H., Umlauf G., Wollgast J.,

2 Zaldívar J.M., Berrojalbiz N., Reuter H.I, Dachs J., 2010. Atmospheric occurrence and

3 deposition of polychlorinated dibenzo-p-dioxins and dibenzofurans (PCDD/Fs) in the open

4 Mediterranean Sea. Environ. Sci. Technol. 44, 5456-5463

6 Cetin B., Odabasi M., 2007. Particle-Phase Dry Deposition and Air-Soil Gas-Exchange of 7 Polybrominated Diphenyl Ethers (PBDEs) in Izmir, Turkey. Environ. Sci. Technol. 41, $8 \quad 4986-4992$

10 Cleverly D., Ferrario J., Byrne C., Riggs K., Joseph D., Hartford P., 2007. A general indication 11 of the contemporary background levels of PCDDs, PCDFs and coplanar PCBs in the ambient 12 air over rural and remote areas of the United States. Environ. Sci. Technol. 41, 1537-1544.

14 Coutinho M., Pereira M., Borrego C., 2007. Monitoring of ambient air PCDD/F levels in 15 Portugal. Chemosphere 67, 1715-1721

17 Cousins, I.T., and Jones K.C., 1998. Air-soil exchange of semi-volatile organic compounds 18 (SOCs) in the UK. Environ. Pollut. 102, 105-118.

Dueri, S. Marinov, D. Fiandrino, A. TronczyGki, J. Zaldívar, J.M., 2010. Implementation of a

21 3D Coupled Hydrodynamic and Contaminant Fate Model for PCDD/Fs in Thau Lagoon 22 (France): The Importance of Atmospheric Sources of Contamination. Int. J. Environ. Res. 
1 Gangnery A., Bacher C., Buestel D., 2001. Assessing the production and the impact of

2 cultivated oysters in the Thau lagoon (Mediterranee, France) with a population dynamics 3 model. Can. J., Fish. Aquat. Sci. 58, 1012-1020.

4

5 Hagenmaier H, Lindig C, She J,. 1994. Correlation of environmental occurrence of 6 polychlorinated dibenzo-p-dioxins and dibenzofurans with possible sources. Chemosphere $7 \quad 29,2163 і ̈ 74$.

8

9 Harrad S.J. and Jones K.C., 1992. A source inventory and budget for chlorinated dioxins 10 and furans in the United Kingdom environment. Sci. Total Environ. 126, 89-107.

12 Hong S-H., Munschy C., Kannan N., Tixier C., Tronczynski J., Héas-Moisan K., and 13 Shima W.J. 2009. PCDD/F, PBDE, and nonylphenol contamination in a semi-enclosed bay 14 (Masan Bay, South Korea) and a Mediterranean lagoon (Thau, France), Chemosphere 77, $15 \quad 854-862$

17 Jaward, F. M.; Farrar, N. J.; Harner, T.; Seweetman, A. J.; Jones, K. C., 2004. Passive air 18 sampling of PCBs, PBDEs and organochlorine pesticides across Europe. Environ. Sci. 19 Technol. 38, 34- 41. 
1 Johansson I, Héas-Moisan K., Guiota N., Munschy C. and Tronczynski J. 2006

2 Polybrominated diphenyl ethers (PBDEs) in mussels from selected French coastal sites:

3 1981-2003. Chemosphere 64, 296-305

4

5 Jurado E., Jaward F.M., Lohmann R., Jones K.C, Simf R., and Dachs J., 2004.

6 Atmospheric dry deposition of persistent organic pollutants to the Atlantic and inferences

7 for the global oceans. Environ. Sci. Technol. 38, 5505-5513.

8

9 Jurado E., Jaward F., Lohmann R., Jones K. C., Simo R., and Dachs J., 2005. Wet 10 deposition of persistent organic pollutants to the global oceans. Environ. Sci. Technol. 39, $11 \quad 2426-2435$.

12

13 Kaupp H., McLachlan M.S., 1999. Atmospheric particle size distributions of 14 polychlorinated dibenzo-p-dioxins and dibenzo-furans (PCDD/Fs) and polycyclic aromatic 15 hydrocarbons (PAHs) and their implications for wet and dry deposition. Atmos. Environ. $16 \quad 33,85-95$.

17

18 Kulkarni P.S., Crespo J.G., Afonso C.A.M., 2008. Dioxin sources and current remediation 19 technologies-A review. Environ. Int. 34, 139-153.

21 Law, R.L., Allchin, C.R., de Boer, J., Covaci, A., Herzke, D., Lepon, P., Morris, S., 22 Tronczynski, J., de Wit, C.A., 2006. Levels and trends of brominated flame retardants in 23 the European environment. Chemosphere 64, 187 ï 208. 
1 Léauté, F., 2008. Biogéochimie des contaminants organiques HAP, PCB et pesticides

2 organochlorés dans les sédiments de lấtang de Thau. Ph.D. Thesis, Université Paris 6, 3 Ifremer.

5 Lee R.G.M., Green N.J.L., Lohmann R., and Jones K., 1999. Seasonal, anthropogenic, air 6 mass, and meteorological influences on the atmospheric concentrations of polychlorinated 7 dibenzo-p-dioxins and dibenzofurans (PCDD/Fs): evidence for the importance of diffuse 8 combustion sources. Environ. Sci. Technol. 33, 2864-2871

9

10 Lin L, Lee W, Li H, Wang M, Chang-Chien G., 2007. Characterization and inventory of $11 \mathrm{PCDD} / \mathrm{F}$ emissions from coal-fired power plants and other sources in Taiwan. 12 Chemosphere 68, $1642 i ̈ 9$.

14 Lohmann R., Green N.J.L. and Jones K.C., 1999a. Atmopheric transport of polychlrinetes 15 debenzo-p-diuoxins and dibenzofurans (PCCD/Fs) in air masses across the United 16 Kingdom and Ireland: Evidence of emissions and depletions. Environ. Sci. Technol. 33, $17 \quad 2872-2878$

19 Lohmann R., Brunciak P., Dachs J., Giglioti C.L., Nelson E., Van Ry D., Glenn T., 20 Eisenreich S.J., Jones J.L. and Jones K.C., 2003. Processes controlling diurnal variations of $21 \mathrm{PCDD} / \mathrm{Fs}$ in the New Jersey coastal atmosphere. Atmos. Environ. 37, 959-969. 
1 Lohmann R.; Green L.J.N., and Jones K.C., 1999b. Detailed studies of the factors

2 controlling atmospheric PCDD/F concentrations. Environ. Sci. Technol. 33, 4440 ï 4447.

4 Lohmann R. and Jones K.C., 1998. Dioxins and furans in air and deposition: a review of 5 levels, behavior and processes. Sci. Total Environ. 219, 53-81.

6

7 Lohmann R., Northcott G.L, Jones K.C., 2000. Assessing the contribution of diffuse 8 domestic burning as a source of PCDD/Fs, PCBs and PAHs to the UK atmosphere. 9 Environ. Sci. Technol. 34:2892ï 9.

11 Mandalakis M., Apostolakis M., and Stephanou E.G., 2005. Mass budget and dynamics of 12 polychlorinated biphenyls in the eastern Mediterranean Sea. Global biogeochem. Cy.19, 13 GB 018, 1-16

15 Mariani G., Canuti E., Castro-Jiménez, J., Christoph E.H., E. Eisenreich S.J., Hanke G., 16 Skejo H., and Umlauf G., 2008. Atmospheric input of POPs into Lake Maggiore (Northern 17 Italy): PBDEs concentrations and profile in air, precipitation, settling material and 18 sediments. Chemosphere 73, S114-S121.

20 Martinez K., Rivera J.A., Jover E., Abalos M., Rivera J., Abad E., 2010. Assessment of the 21 emission of PCDD/Fs and dioxin-like PCBs from an industrial area over a nearby town using 22 a selective wind direction sampling device. Environ. Pollut. 158, $764 і ̈ 769$. 
1 Munschy C., Guiota N., Héas-Moisan K. Tixier C., and Tronczynski J., 2008.

2 Polychlorinated dibenzo-p-dioxins and dibenzofurans (PCDD/Fs) in marine mussels from

3 French coasts: Levels, patterns and temporal trends from 1981 to 2005. Chemosphere 73,

$4 \quad 945-953$

5

6 Plan Régional pour la Qualité de lôAir (PRQA). Prefecture de la Region Languedoc-

$7 \quad$ Roussillon, November 1999, pp 34-35

8

9 Quaß U., Fermann M., Gunter B., 2004. The European Dioxin Air Emission Inventory

10 Projectï Ï Final Results. Chemosphere 54, $1319 і ̈ 1327$.

11

12 Réseau dổbservation de la contamination Chimique (ROCCH)

13 (http://www.ifremer.fr/envlit/surveillance/contaminants-chimiques)

14

15 Registre Français des Emissions Polluantes (RFEP)

16 http://www.pollutionsindustrielles.ecologie.gouv.fr/IREP/index.php

17

18 Safe S., 1984. Polychlorinated biphenyls (PCBs) and polybrominated biphenyls (PBBs):

19 Biochemistry, toxicology and mechanism of action. Crit. Rev. Toxicol. 13, 319-395.

21 Safe S., 1990. Polychlorinated biphenyls (PCBs), dibdenzo-p-dioxins (PCDDs), 22 dibenzofurans (PCDFs) and related compounds: Environmental and mechanistic 
1 considerations which support the development of toxic equivalency factors (TEFs). Crit.

2 Rev. Toxicol. 21, 51-88.

4 TronczyGki 1998. In Surveillance du milieu marin. Travaux du Réseau National 5 dôObservation du milieu marin. Edition 1998.

6

7 Tysclind M., Fangmark I., Marklund S., Lindskog A., Thaning L., and Rappe C., 1993.

8 Atmospheric transport and transformation of polychlorinated dibenzo-p-dioxins and 9 dibenzofurans. Environ. Sci. Technol. 27, 2190-2197.

11 U.S. Environmental Protection Agency 1999a. Method TO-9A. Determination of 12 polychlorinated, polybrominated and brominated /chlorinated dibenzo-p-dioxins and 13 dibenzofurans in ambient air. In Compendium of methods for the determination of toxic 14 organic compounds in ambient air, $2^{\text {nd }}$ ed.; EPA/625/R-96/010b; Washington, DC.

15

16 U.S. EPA., 1994. Method 1613: Tetra-through Octa-Chlorinated Dioxins and Furans by 17 Isotope Dilution HRGC/HRMS.U.S. EPA., 1999. Method 1668, revision A: Chlorinated 18 Biphenyl Congeners in Water, Soil, Sediment and Tissue by HRGC/HRMS.

20 U.S. EPA., 1999b. Method 1668, revision A: Chlorinated Biphenyl Congeners in Water, 21 Soil, Sediment and Tissue by HRGC/HRMS. 
1 US EPA., 2003. Method 1614: Brominated diphenyl ethers in water, soil, sediment, and

2 tissue by HRGC/HRMS.

4 Vives I., Canuti E., Castro-Jiménez J., Christoph E.H., Eisenreich S.J., Hanke G., Huber T.,

5 Mariani G., Mueller A., Skejo H. Umlauf G., Wollgast J., 2007. Occurrence of 6 polychlorinated dibenzo-p-dioxins and dibenzofurans (PCDD/Fs), polychlorinated 7 biphenyls (PCBs) and polybrominated diphenyls ethers (PBDEs) in Lake Maggiore (Italy 8 and Switzerland). J. Environ. Monit. 9, 589-598.

9

10 Vreugdenhil, H. J. I., Lanting C.I., Mulder P.G.H, Boersma E.R. and Weisglas-Kuperus N., 11 2002. Effects of prenatal PCB and dioxin background exposure on cognitive and motor 12 abilities in Dutch children at school age. J. Pediatr. 140, $48 і ̈ 56$.

13

14 Wania F. and Mackay D.,1996. Tracking the distribution of persistent organic pollutants, 15 Environ. Sci. Technol. 30, 390Aï 396A.

16 Zhang B. Meng F., Shi C., Yang F., Wen D, Aronsson J, Gbor P.K., Sloan J.J., 2009.

17 Modeling the atmospheric transport and deposition of polychlorinated dibenzo-p-dioxins

18 and dibenzofurans in North America. Atmos. Environ. 43, 2204ї 2212

19

20 Zhu J., Hirai Y., Yu G., Sakai S., 2008 Levels of PCDD and PCDF in China and 21 chemometric analysis of potential emission sources. Chemosphere 70, 703-711 
FIGURES

Figure 1
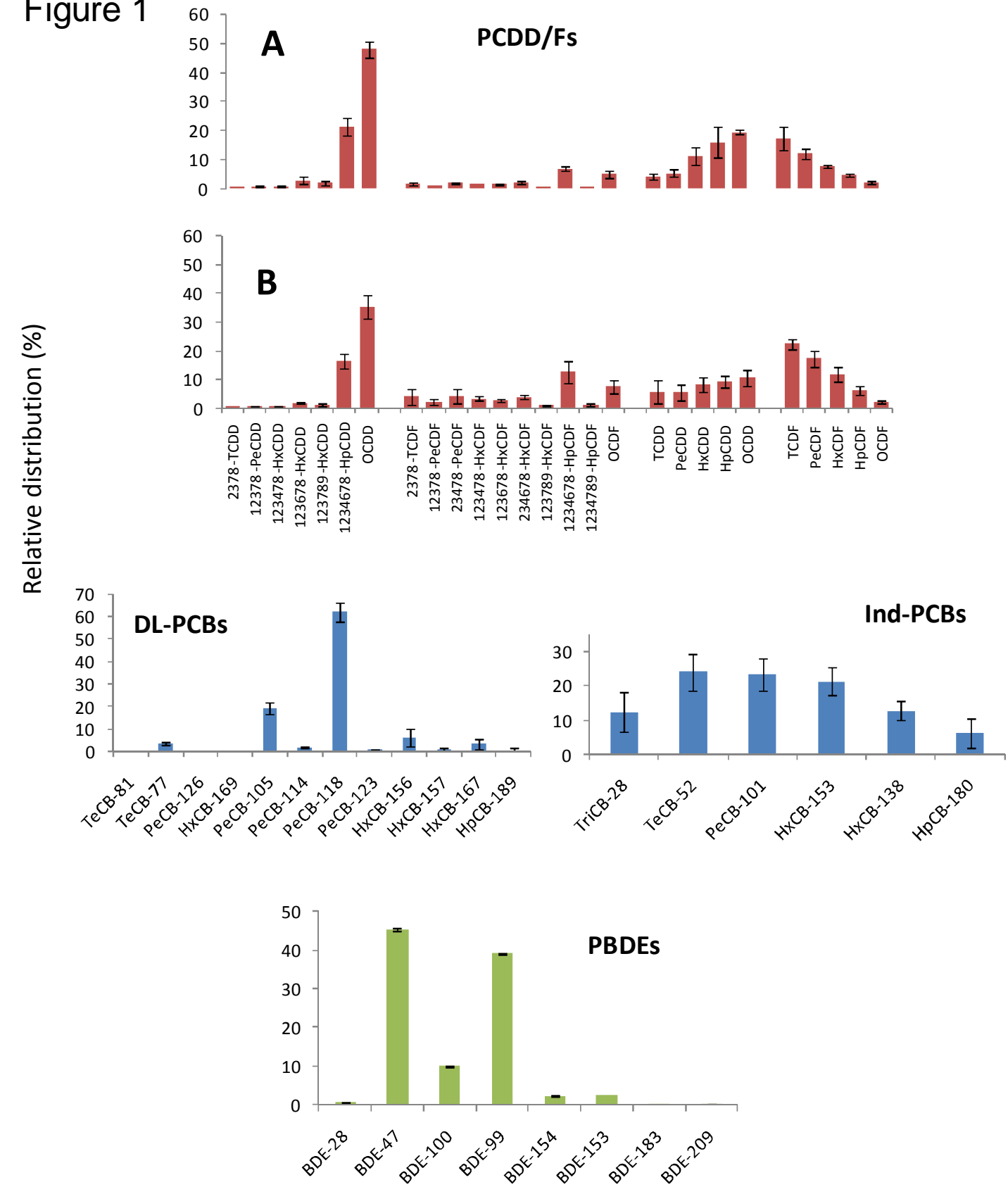

3 Figure 1. PCDD/F, PCB and PBDE congener pattern observed in Thau lagoon airshed from February 2007 to 42008 . 

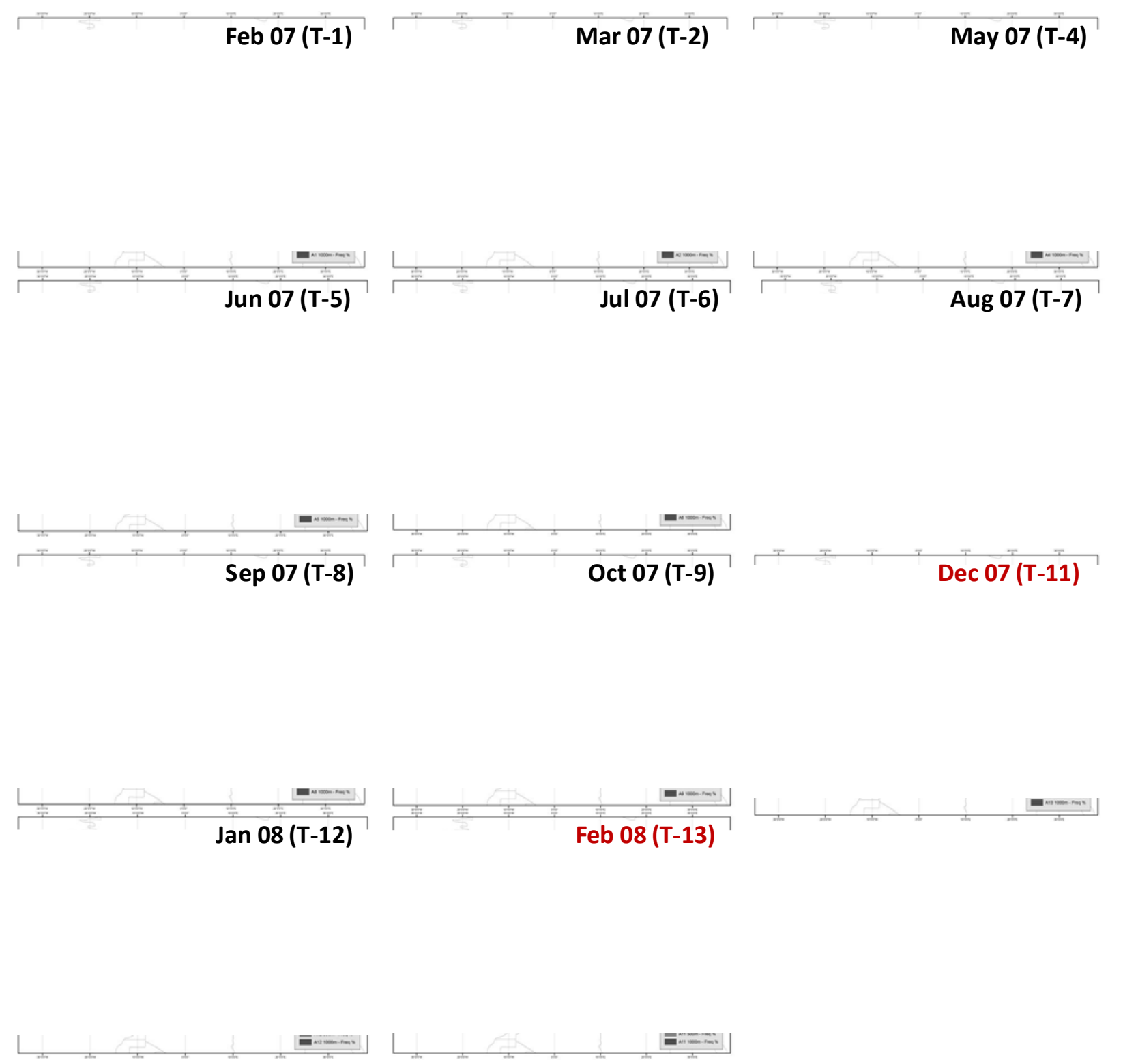
1 Figure 2. Overlay of back trajectories (120h) frequency plots at 50, 100, 500 and 1000m (not considering BTs frequency $<10 \%$ ). Trajectories were

2 calculated from the sampling location (cross in the map) every 6 hours during the sampling week. Black labels are trajectories presenting a NW

3 Atlantic/marine influence (T1-9, T12) and red labels are trajectories presenting a continental influence (T11 and T13). 


\section{Figure 3}

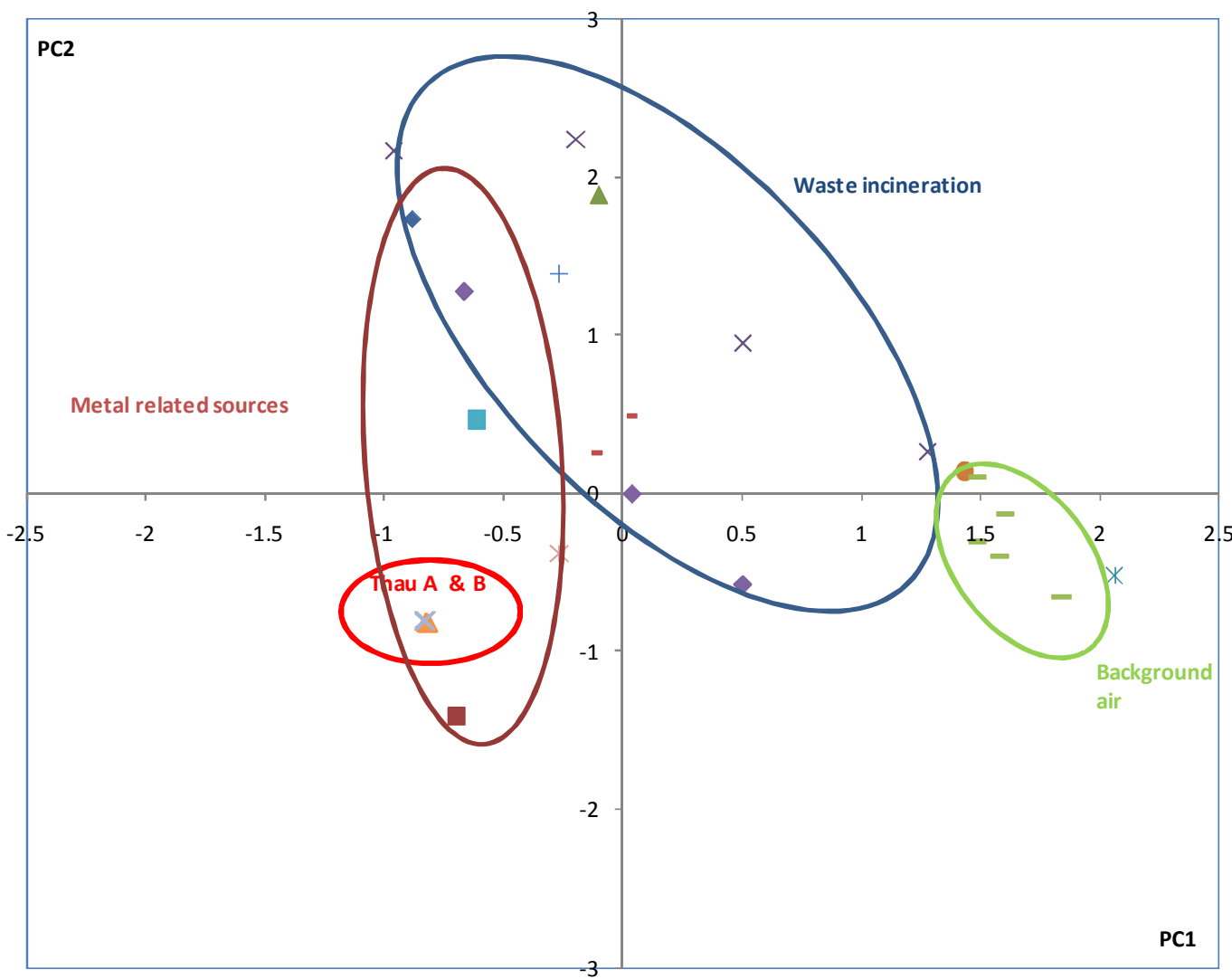

X-exp: $54 \%, 16 \%$

$\checkmark$ copper smelter

$\square$ aluminium plant

$\triangle P V C$ combustion

$X$ waste incineration

$*$ Diesel fuel vehicles

* Pb fuel

No-Pb fuel

+ Utilities and industrial boilers

- Coal Power Plant

- Background Air sample

- MWI Gas

Metal processing

$\triangle$ Thau $\mathrm{A}$

3 Figure 3. Principal component analysis (PCA) score plot of PCDD/F air samples collected in Thau lagoon

4 and samples related to PCDD/F emission sources and background sites from literature.

5 
PCDD/Fs
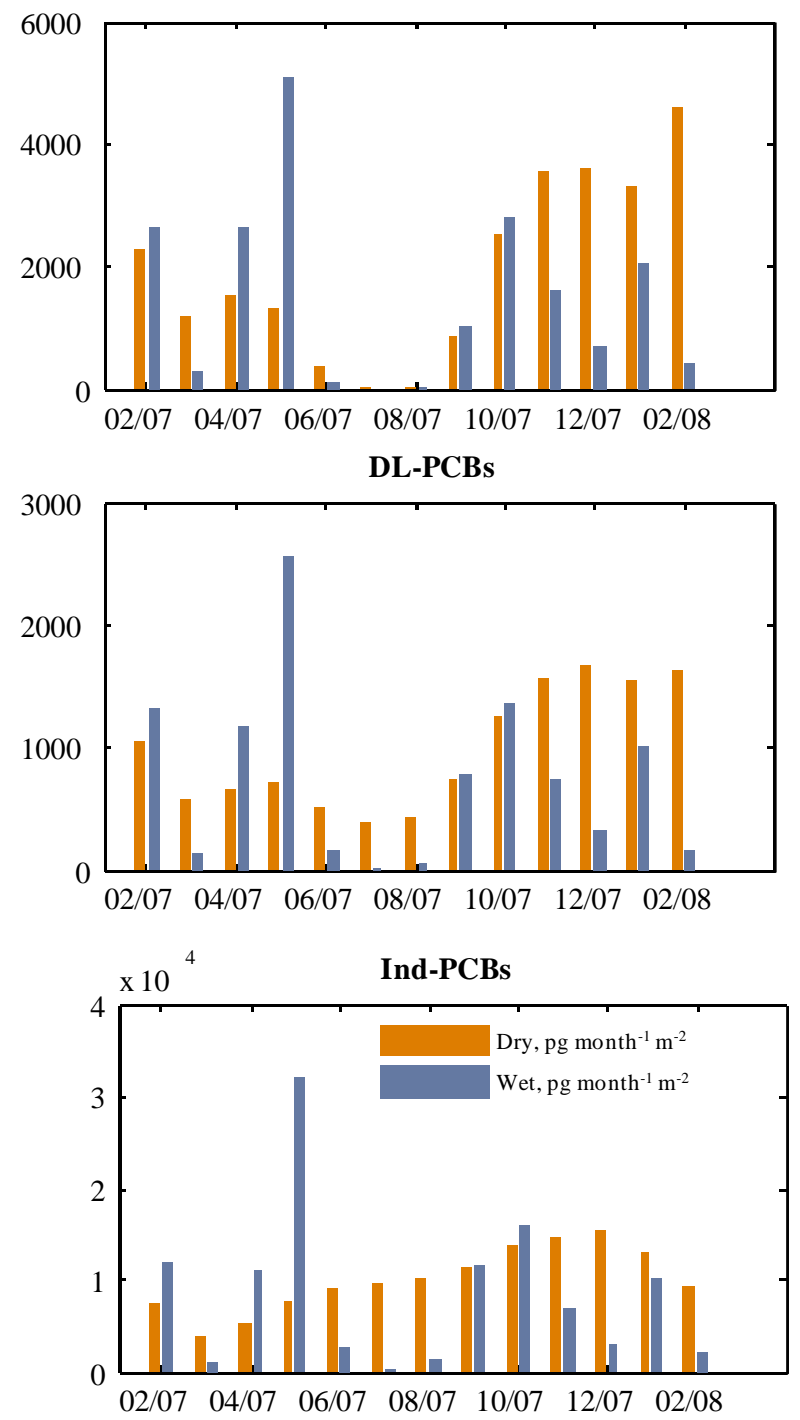

2

3 Figure 4. PCDD/F and PCB deposition fluxes (dry and wet) to Thau lagoon waters during the period

4 February 2007-2008

5 
1 Table 1. PCDD/F atmospheric concentrations (gas + particulate) in the airshed of Thau 2 lagoon (2007-2008). Concentrations are $\mathrm{fg} \mathrm{m}^{-3}$

Table 1. PCDD/Fs atmospheric concentrations (gas + particulate) in the airshed of Thau Lagoon (2007-2008). Concentrations are fg $\mathrm{m}^{-3}$

\begin{tabular}{|c|c|c|c|c|c|c|c|c|c|c|c|}
\hline Sample month/code & Feb-07 & Mar-07 & May-07 & Jun-07 & Jul-07 & Aug-07 & Sep-07 & Oct- 07 & Dec-07 & Jan -08 & Feb-08 \\
\hline 2,3,7,8-PCDD/Fs & $\mathrm{T}-1$ & $\mathrm{~T}-2$ & $\mathrm{~T}-4$ & $\mathrm{~T}-5$ & $\mathrm{~T}-6$ & $\mathrm{~T}-7$ & $\mathrm{~T}-8$ & $\mathrm{~T}-9$ & $\mathrm{~T}-11$ & $\mathrm{~T}-12$ & $\mathrm{~T}-13$ \\
\hline $2,3,7,8-\mathrm{TCDD}$ & 0.46 & 0.90 & 0.25 & 0.23 & 0.19 & 0.06 & 0.11 & 0.32 & 2.59 & 0.58 & 2.12 \\
\hline 1,2,3,7,8-PeCDD & 3.06 & 5.42 & 1.43 & 0.48 & 0.36 & 0.44 & 0.67 & 0.94 & 18.00 & 1.77 & 7.67 \\
\hline 1,2,3,4,7,8-HxCDD & 3.88 & 3.93 & 1.26 & 0.56 & 0.25 & 0.30 & 0.74 & 1.72 & 15.03 & 2.68 & 9.48 \\
\hline 1,2,3,6,7,8-HxCDD & 12.70 & 19.95 & 4.94 & 1.44 & 1.18 & 1.13 & 3.04 & 5.79 & 57.00 & 8.25 & 25.82 \\
\hline 1,2,3,7,8,9-HxCDD & 9.29 & 12.98 & 3.28 & 0.82 & 0.58 & 0.88 & 1.86 & 4.25 & 35.00 & 6.20 & 17.68 \\
\hline 1,2,3,4,6,7,8-HpCDD & 119.78 & 95.19 & 35.72 & 11.22 & 13.23 & 11.20 & 16.43 & 55.40 & 380.90 & 74.91 & 262.78 \\
\hline OCDD & 264.53 & 199.81 & 65.92 & 24.28 & 32.07 & 34.74 & 37.42 & 110.11 & 699.87 & 161.55 & 599.63 \\
\hline 2,3,7,8-TCDF & 8.27 & 6.94 & 3.92 & 2.85 & 2.63 & 1.64 & 4.01 & 5.78 & 27.56 & 5.52 & 166.95 \\
\hline $1,2,3,7,8-\mathrm{PeCDF}$ & 5.82 & 5.90 & 2.35 & 1.29 & 1.58 & 0.75 & 2.97 & 4.37 & 15.71 & 3.72 & 71.78 \\
\hline $2,3,4,7,8-\mathrm{PeCDF}$ & 10.99 & 9.73 & 4.95 & 2.89 & 1.99 & 1.05 & 6.03 & 8.25 & 36.95 & 6.97 & 153.04 \\
\hline $1,2,3,4,7,8-\mathrm{HxCDF}$ & 8.71 & 7.60 & 4.41 & 2.26 & 3.01 & 1.23 & 5.83 & 7.44 & 24.60 & 5.48 & 67.93 \\
\hline $1,2,3,6,7,8-\mathrm{HxCDF}$ & 8.32 & 7.99 & 4.79 & 2.04 & 2.18 & 1.02 & 5.15 & 7.42 & 20.91 & 5.24 & 51.59 \\
\hline 2,3,4,6,7,8-HxCDF & 10.53 & 9.63 & 8.13 & 2.83 & 2.70 & 1.77 & 7.51 & 9.72 & 30.37 & 8.69 & 56.71 \\
\hline $1,2,3,7,8,9-\mathrm{HxCDF}$ & 3.41 & 3.04 & 2.27 & 0.72 & 0.47 & 0.43 & 1.79 & 2.80 & 8.62 & 2.50 & 18.17 \\
\hline $1,2,3,4,6,7,8-\mathrm{HpCDF}$ & 35.29 & 32.44 & 24.21 & 9.71 & 11.62 & 5.23 & 23.94 & 33.94 & 86.10 & 25.91 & 103.04 \\
\hline $1,2,3,4,7,8,9-\mathrm{HpCDF}$ & 4.70 & 4.08 & 3.27 & 0.92 & 0.58 & 0.65 & 3.07 & 3.89 & 12.82 & 3.06 & 15.79 \\
\hline OCDF & 23.40 & 23.56 & 13.96 & 4.60 & 8.17 & 4.78 & 14.10 & 21.02 & 57.20 & 15.04 & 69.39 \\
\hline$\times 2,3,7,8-P C D D s$ & 413.70 & 338.19 & 112.80 & 39.03 & 47.86 & 48.75 & 60.27 & 178.53 & 1208.39 & 255.95 & 925.18 \\
\hline$\times 2,3,7,8-P C D F s$ & 119.43 & 110.91 & 72.26 & 30.11 & 34.93 & 18.55 & 74.40 & 104.63 & 320.84 & 82.14 & 774.40 \\
\hline$\times 2,3,7,8-\mathrm{PCDD} / \mathrm{Fs}$ & 533.14 & 449.10 & 185.05 & 69.14 & 82.80 & 67.30 & 134.67 & 283.16 & 1529.23 & 338.09 & 1699.58 \\
\hline WHO-TEQ ${ }_{98}{ }^{a}$ & 17.44 & 20.03 & 8.21 & 3.79 & 3.19 & 2.08 & 7.37 & 11.05 & 66.64 & 11.54 & 135.21 \\
\hline WHO-TEQ $Q_{05}{ }^{a}$ & 15.18 & 18.01 & 7.19 & 3.19 & 2.77 & 1.87 & 6.12 & 9.34 & 59.09 & 10.11 & 103.30 \\
\hline \multicolumn{12}{|l|}{$\mathrm{Cl}_{4-8-\mathrm{PCDD} / \mathrm{Fs}}$} \\
\hline TCDD & 45.40 & 45.25 & 35.34 & 45.63 & 9.00 & 6.72 & 27.39 & 35.85 & 139.13 & 52.11 & 100.14 \\
\hline PeCDD & 56.09 & 63.68 & 37.71 & 37.15 & 7.73 & 7.13 & 31.39 & 36.27 & 233.78 & 54.57 & 130.21 \\
\hline $\mathrm{HxCDD}$ & 123.30 & 139.89 & 60.76 & 43.37 & 14.68 & 12.99 & 35.28 & 68.86 & 552.87 & 97.05 & 301.69 \\
\hline HpCDD & 282.91 & 163.48 & 65.88 & 23.67 & 22.81 & 20.44 & 33.41 & 99.62 & 776.23 & 86.91 & 477.11 \\
\hline OCDD & 264.53 & 199.81 & 65.92 & 24.28 & 32.07 & 34.74 & 37.42 & 110.11 & 699.87 & 161.55 & 599.63 \\
\hline TCDF & 210.25 & 180.78 & 122.59 & 69.38 & 62.10 & 39.48 & 113.02 & 197.45 & 433.50 & 157.76 & 1066.13 \\
\hline PeCDF & 134.55 & 128.24 & 92.85 & 48.98 & 44.93 & 26.00 & 96.76 & 132.83 & 399.79 & 103.89 & 988.42 \\
\hline $\mathrm{HxCDF}$ & 94.69 & 84.72 & 64.91 & 30.08 & 33.94 & 13.35 & 80.79 & 93.89 & 257.96 & 70.22 & 550.07 \\
\hline $\mathrm{HpCDF}$ & 57.95 & 52.81 & 40.83 & 16.65 & 19.44 & 8.77 & 39.26 & 55.48 & 148.96 & 41.99 & 172.15 \\
\hline OCDF & 23.40 & 23.56 & 13.96 & 4.60 & 8.17 & 4.78 & 14.10 & 21.02 & 57.20 & 15.04 & 69.39 \\
\hline$\times \mathrm{Cl}_{4-8}$-PCDDs & 772.23 & 612.12 & 265.62 & 174.10 & 86.29 & 82.01 & 164.89 & 350.71 & 2401.88 & 452.19 & 1608.78 \\
\hline$\times \mathrm{Cl}_{4-8}-\mathrm{PCDFs}$ & 520.84 & 470.11 & 335.13 & 169.68 & 168.58 & 92.38 & 343.92 & 500.66 & 1297.41 & 388.90 & 2846.15 \\
\hline$\times \mathrm{Cl}_{4-8}-\mathrm{PCDD} / \mathrm{Fs}$ & 1293.07 & 1082.23 & 600.75 & 343.78 & 254.87 & 174.39 & 508.81 & 851.38 & 3699.30 & 841.10 & 4454.94 \\
\hline
\end{tabular}


1 Table 2. PCB atmospheric concentrations (gas + particulate) in the airshed of Thau lagoon (2007-2008). Concentrations are pg $2 \mathrm{~m}^{-3}$

3

4

\begin{tabular}{|c|c|c|c|c|c|c|c|c|c|c|c|c|c|}
\hline Sample month/code & Feb-07 & Mar-07 & Apr-07 & May-07 & Jun-07 & Jul-07 & Aug-07 & Sep-07 & Oct-07 & Nov-07 & Dec-07 & Jan-08 & Feb-08 \\
\hline Congeners & $\mathrm{T}-1$ & $\mathrm{~T}-2$ & $\mathrm{~T}-3$ & $\mathrm{~T}-4$ & T-5 & T-6 & T-7 & $\mathrm{T}-8$ & T-9 & T-10 & $\mathrm{T}-11$ & $\mathrm{~T}-12$ & $\mathrm{~T}-13$ \\
\hline \multicolumn{14}{|l|}{ Non-ortho PCBs } \\
\hline TeCB-81 & 0.007 & 0.006 & 0.006 & 0.008 & 0.008 & 0.009 & 0.003 & 0.009 & 0.007 & 0.003 & 0.008 & 0.004 & 0.013 \\
\hline TeCB-77 & 0.096 & 0.089 & 0.132 & 0.155 & 0.190 & 0.246 & 0.089 & 0.190 & 0.134 & 0.040 & 0.086 & 0.052 & 0.139 \\
\hline PeCB-126 & 0.012 & 0.012 & 0.013 & 0.015 & 0.019 & 0.022 & 0.010 & 0.019 & 0.016 & 0.005 & 0.020 & 0.008 & 0.059 \\
\hline HxCB-169 & 0.002 & 0.002 & 0.001 & Ò.001 & 0.001 & 0.001 & 0.001 & 0.001 & 0.002 & ò.001 & 0.005 & 0.001 & 0.012 \\
\hline \multicolumn{14}{|l|}{ Mono-ortho PCBs } \\
\hline PeCB-105 & 0.664 & 0.480 & 0.671 & 0.670 & 0.859 & 1.122 & 0.446 & 0.914 & 0.697 & 0.234 & 0.674 & 0.363 & 0.931 \\
\hline PeCB-114 & 0.061 & 0.054 & 0.067 & 0.061 & 0.085 & 0.103 & 0.040 & 0.091 & 0.074 & 0.024 & 0.050 & 0.036 & 0.126 \\
\hline PeCB-118 & 1.929 & 1.511 & 2.184 & 2.187 & 2.768 & 3.592 & 1.416 & 3.005 & 2.240 & 0.799 & 2.002 & 1.209 & 3.856 \\
\hline PeCB-123 & 0.030 & 0.020 & 0.032 & 0.045 & 0.041 & 0.063 & 0.030 & 0.042 & 0.030 & 0.011 & 0.022 & 0.019 & 0.047 \\
\hline HxCB-156 & 0.196 & 0.141 & 0.155 & 0.204 & 0.192 & 0.249 & 0.099 & 0.200 & 0.166 & 0.046 & 0.256 & 0.104 & 1.455 \\
\hline HxCB-157 & 0.034 & 0.024 & 0.025 & 0.102 & 0.031 & 0.065 & 0.020 & 0.031 & 0.028 & 0.008 & 0.051 & 0.016 & 0.165 \\
\hline HxCB-167 & 0.100 & 0.076 & 0.092 & 0.086 & 0.114 & 0.142 & 0.060 & 0.120 & 0.094 & 0.027 & 0.112 & 0.059 & 0.779 \\
\hline НpCB-189 & 0.017 & 0.014 & 0.013 & 0.011 & 0.011 & 0.012 & 0.005 & 0.013 & 0.013 & 0.002 & 0.032 & 0.011 & 0.283 \\
\hline WHO-TEQ ${ }_{98}^{a}\left(\mathrm{fg} \mathrm{m}^{-3}\right)$ & 1.689 & 1.511 & 1.738 & 2.040 & 2.481 & 2.904 & 1.238 & 2.489 & 2.023 & 0.615 & 2.508 & 1.083 & 7.391 \\
\hline WHO-TEQ $Q_{05}{ }^{a}\left(\mathrm{fg} \mathrm{m}^{-3}\right)$ & 1.409 & 1.301 & 1.443 & 1.685 & 2.098 & 2.399 & 1.043 & 2.090 & 1.728 & 0.510 & 2.244 & 0.918 & 6.466 \\
\hline \multicolumn{14}{|l|}{ Indicator PCBs } \\
\hline TriCB-28 & 5.31 & 2.58 & 5.38 & 4.54 & 2.88 & 2.33 & 2.58 & 1.98 & 1.04 & 2.87 & 1.34 & 3.25 & 6.63 \\
\hline TeCB-52 & 5.89 & 4.85 & 7.97 & 7.32 & 8.07 & 8.92 & 4.52 & 5.66 & 6.10 & 3.73 & 4.54 & 4.21 & 7.34 \\
\hline PeCB-101 & 5.04 & 4.29 & 6.95 & 6.54 & 7.98 & 9.85 & 3.77 & 8.69 & 6.60 & 2.30 & 3.66 & 3.37 & 10.47 \\
\hline HxCB-153 & 4.71 & 3.68 & 5.51 & 5.09 & 6.98 & 8.16 & 3.09 & 7.19 & 5.41 & 1.48 & 3.10 & 2.92 & 27.87 \\
\hline HxCB-138 & 2.87 & 2.15 & 3.16 & 2.92 & 3.95 & 4.78 & 1.81 & 4.13 & 3.21 & 0.83 & 2.39 & 1.64 & 17.27 \\
\hline HpCB-180 & 1.53 & 1.08 & 1.34 & 1.11 & 1.63 & 1.74 & 0.66 & 1.55 & 1.24 & 0.25 & 1.18 & 0.82 & 16.99 \\
\hline$\times$ DL-PCBs & 3.15 & 2.43 & 3.39 & 3.54 & 4.32 & 5.62 & 2.22 & 4.64 & 3.50 & 1.20 & 3.32 & 1.88 & 7.64 \\
\hline Xindicator PCBs & 25.36 & 18.62 & 30.31 & 27.53 & 31.48 & 35.78 & 16.43 & 29.21 & 23.60 & 11.46 & 16.20 & 16.20 & 86.58 \\
\hline$\times 18 \mathrm{PCBs}$ & 28.50 & 21.05 & 33.71 & 31.07 & 35.80 & 41.41 & 18.65 & 33.84 & 27.10 & 12.65 & 19.52 & 18.08 & 94.44 \\
\hline Values (Ò) are limits of dete & on and are & idered in & totals, ${ }^{a}$ T & values a & pper boun & concentrat & & & & & & & \\
\hline
\end{tabular}


1 Table 3. Indicative hot season PBDE atmospheric concentrations (gas + particulate) in the 2 airshed of Thau lagoon (May-August 2007). Concentrations are $\mathrm{pg} \mathrm{m}^{-3}$

3

4

5
6

\begin{tabular}{|c|c|c|c|}
\hline Sample month/code & May-07 & Jul-07 & Aug-07 \\
\hline Congeners & $\mathrm{T}-4$ & $\mathrm{~T}-6$ & $\mathrm{~T}-7$ \\
\hline BDE-28 & 1.28 & 1.05 & 0.81 \\
\hline BDE-47 & 103.49 & 93.24 & 70.89 \\
\hline BDE-100 & 23.14 & 19.94 & 16.02 \\
\hline BDE-99 & 89.67 & 79.00 & 61.96 \\
\hline BDE-154 & 5.49 & 4.77 & 3.81 \\
\hline BDE-153 & 5.70 & 5.03 & 4.02 \\
\hline BDE-183 & 0.20 & 0.11 & 0.09 \\
\hline BDE-209 & 1.38 & 1.35 & 0.77 \\
\hline Ù8 PBDEs & 230.35 & 204.48 & 158.38 \\
\hline
\end{tabular}


Table 4. Annual atmospheric inputs of POPs into Thau lagoon (dry and wet deposition as mass and TEQ fluxes)

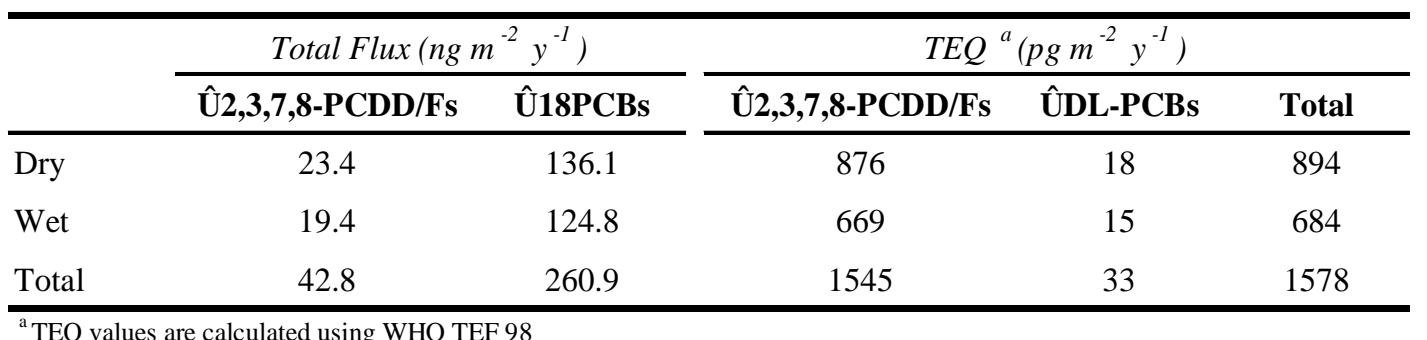

5 